\title{
Structure of the Northern Bay of Bengal offshore Bangladesh: Evidences from new multi-channel seismic data
}

\author{
Rangin Claude ${ }^{1,{ }^{*}}$, Sibuet Jean-Claude ${ }^{2,3}$ \\ ${ }^{1}$ GEOAZUR, Université Nice Sophia Antipolis, Av. A. Einstein, Valbonne, France \\ ${ }^{2} 44$ rue du Cloitre, 29280 Plouzané, France \\ ${ }^{3}$ Ifremer Centre de Brest, BP 70, 29280 Plouzané Cedex, France \\ * Corresponding author : Claude Rangin, email address : claude@rangin.fr
}

\begin{abstract}
:
New multi-channel seismic data were acquired in the northern part of the Bay of Bengal and at the northernmost termination of the $90^{\circ} \mathrm{E}$ Indian Ridge offshore Bangladesh. This survey was coupled with a seismic refraction experiment indicating this offshore basin is here floored by a thinned (15 km thick) continental crust, injected by Mesozoic volcanism. This attenuated continental crust is interpreted as formed during Gondwana super-continent fragmentation during a syn-rift period. The dominant tectonic pattern is marked by NE-SW trending tilted blocks filled by syn-rift sediments clearly identified on seismic profiles. The uppermost part of this continental crust (3-4 km thick) shows a complex assemblage of dipping reflectors and west-facing tilted blocks injected by volcanic build-ups. The lower crustal sequence (11-12 km thick) does not reveal significant reflectors. This syn-rift fabric is attributed to the Mesozoic up to the Early Cretaceous by correlation with published seismic data along the eastern coast of India. Opposite normal faults vergency on the Indian and Burma sides indicate an asymmetrical rifting (simple shear) creating a wide COT on the Burma side and a short COT on the opposite Indian side, a geometry typical of continental crust stretching.
\end{abstract}

This crustal fabric is overlain disconformably by a thin reflector attributed to the Late CretaceousPaleocene pelagic sequence deposited during India/Bay of Bengal drift phase, before the CenozoicIndia Asia collision marked by thick clastic sedimentation associated with the Ganges delta southward progradation.

Below this delta, this Mesozoic rift closes axially and is affected by the incipient Late Miocene shortening of the Shillong Plateau. The NE-SW fabric of this attenuated crust might be traced southward to $15^{\circ} \mathrm{N}$, close to magnetic chron 34 , where steady state spreading of the Central Indian Ocean occurred.

Keywords : Bengal basin, Seismic analysis, Basin structure, Bengladesh 
31 The Bay of Bengal extends into the northernmost part of the Indian Ocean. It is $1500 \mathrm{~km}$ wide at

$3215^{\circ} \mathrm{N}$, between the East India passive margin to the west and the Sunda plate margin to the East.

33 This basin was formed during two successive spreading episodes. Its northern part is generally

34 accepted as floored oceanic crust formed during the Cretaceous and is characterized by NE-SW

35 trending magnetic anomalies and possible NW-SE trending transform faults (Curray et al., 1982;

36 Subrahmanyam et al., 1999). However Brune and Singh (1986) suspected the presence of

37 continental crust flooring this basin. Southward, the Central Indian Ocean is clearly oceanic with

38 E-W trending magnetic anomalies and N-S trending transform faults (Royer et al., 1988).

39 According to Gibbons et al. (2013) the transition from the NE-W to E-W trending magnetic

40 lineations occurred at 100 Ma (Figure 1), testifying for a possible transition between the

41 termination of the Gondwana rifting and the onset of the incipient drift of India.

\section{Previous basement studies in the northern Bay of Bengal}

43 Magnetic anomalies identification and ages in the northern Bay of Bengal are still a matter of

44 debate among the scientific community. The supposedly oceanic crust is generally accepted as

45 Early Cretaceous in age and then developed during the magnetic quiet period (Ramana et al., 46 1994). 
Curray and Munasinghe (1991) suspected magnetic anomalies M4 and M5 in this basin, meanwhile Ramana et al. (1994) proposed a M11-M0 magnetic model for this basin, with a halfspreading rate of $3.5 \mathrm{~cm} / \mathrm{yr}$. More recently, Desa et al. (2013) considered the Bengal basin as the drifted half part of the Early Cretaceous Enderby basin. Barnerjee et al. (1995) proposed the rifting of this basin was generated above the same hot spot (Rajmahal/Kerguelen) induced by the Barremian India/Antarctica rifting. The crust of the basin could be then considered as a drifted part of the Kerguelen Large Igneous Province (LIP). In the eastern part of the basin, gravity data revealed the presence of NE-SW trending highs and lows along the coast of KrishnaGodavari and Mahanadi. The gravity lows correspond to the infilling of Permian, Triassic and Early Cretaceous sediments (Bastia and Radhakrihna, 2012; Nemcok et al., 2012 and Sandwell et al., 2014) with NE-SW trending lows and highs truncated and offset by NNW-SSE transverse zones that could be interpreted as oceanic fracture zones.

Rao et al. (1997) proposed that the oldest sediments deposited on the supposed oceanic crust are Early Cretaceous in age along the East India coast, and have identified eight distinct overlying sedimentary sequences ranging from Eocene to Late Pleistocene. Curray et al. (1982) compiled all seismic refraction data set available at this time. They found crustal velocities of 6.4 $\mathrm{km} / \mathrm{s}$ in the Cauvery basin at $10^{\circ} \mathrm{N}$ and $13^{\circ} \mathrm{N}$ with an onset of sedimentation during Albian (or older) age and Early Cretaceous, respectively. Desa et al. (2013) suggest an Early Cretaceous age for the onset of rifting in the Bengal basin along the eastern margin of India. An eastward transition with a possible oceanic crust was proposed by Nemcok et al. (2012).

The eastern part of the basin, where the $90^{\circ} \mathrm{E}$ Ridge is largely present, was drilled during DSDP leg 22 (Site 217, Moore et al., 1974). A rather continuous sequence from Quaternary to Middle Late Miocene was drilled down to the bottom of the $600 \mathrm{~m}$ thick basal Campanian chalks and cherts deposited on the $90^{\circ} \mathrm{E}$ Ridge basement. Between $10^{\circ} \mathrm{N}$ and $17^{\circ} \mathrm{N}$, a Quaternary to Eocene sedimentary sequence was locally deposited on these volcanic rocks. These volcanics were attributed to the drifted Kerguelen hot spot LIP (Coffin et al., 2002, Figure 1), but are frequently 
73

younger than the LIP itself. Royer et al. (1988) on drilling sites ODP leg 121, show a N to S decreasing age for this ridge volcanism (90 to $38 \mathrm{Ma}$ ), from $35^{\circ} \mathrm{N}$ to $10^{\circ} \mathrm{N}$ respectively (Duncan and Storey, 1993). This fits rather well the decreasing age of the South Bengal basin and Wharton spreading centers on both sides of the ridge. However, part of this Cretaceous and Cenozoic volcanism could be interpreted as MORB volcanism injected along the $90^{\circ} \mathrm{E}$ transform fault during the active South Bengal/Wharton basins spreading center migrations (Sclater and Fisher, 1974).

Mukhopadday and Krishna (1991), Klootwijk et al. (1991) and Duncan and Storey (1993) also suggested that part of this ridge volcanism has a MORB signature, which could have been injected from this spreading center over an attenuated ridge crust estimated 25 -km thick by Greyvemeyer et al. (1999).

Le Pichon and Heirtzler (1968) have noticed exhumed gabbro along the $90^{\circ}$ E Ridge. Consequently, the $90^{\circ} \mathrm{E}$ Indian Ridge is a topographic high probably formed during early Cenozoic intraplate shortening facilitating doming and exhumation of mantle, and underplated spreading center volcanism injected along the previously existing transform boundary. Maurin and Rangin (2009a) were able to trace the $90^{\circ} \mathrm{E}$ Ridge up to $20^{\circ} \mathrm{N}$ in our study area.

Data on the pre-Cenozoic stratigraphy, the nature and age of the northern Bay of Bengal acoustic basement are scarce, due to the lack of deep seismic penetration lines and deep well data. The most reliable seismic and drilling data were acquired in the western part of the basin, along the Eastern continental margin of the India micro-continent. Multi-channel seismic (MCS) data, calibrated by wells, were published by Bastia and Radhakrishna (2012). They interpret the western flank of this basin as a starved passive margin. Here, the deepest seismic horizons were reached by drilling and sediments were dated Valanginian.

Eastward, recent oil and gas exploration is presently intensifying offshore Bangladesh and Myanmar, but most of the wells did not reach the Paleogene and still remain confidential. Part of 
our new MCS data collected offshore western Myanmar in 2006 (Maurin and Rangin, 2009b) and partly used in this paper, were only calibrated for the Neogene.

On land, the most representative sequence that could be eventually correlated with the studied offshore area, crops out in the Rajmahal area, which has a special significance for the rifting and drifting history of the Bay of Bengal. Here, Precambrian metamorphosed continental rocks and tholeiitic lava trap flows (Rajmahal volcanic traps) were found. Hornblende and olivine basalts, andesite and intercalations of tuffs and ashes dated between 118 and 115 Ma mainly form this hot spot volcanism (Kent et al., 2002). It is generally interpreted as a drifted fragment of the Kerguelen Large Igneous Province (LIP). In Bangladesh, this volcanism is disconformably covered by a few hundred meters of coarse sandstones and argillites (Alam et al., 2003) reworking the underlying volcanic rocks.

The terminal stage for cessation of LIP Rajmahal volcanism was dated around $117 \mathrm{Ma}$ (Kent et al., 2002). Consequently, the cessation of North Bay of Bengal rifting has to be of the same age. Drifting of India along the $90^{\circ} \mathrm{E}$ Ridge was dated 84-82 Ma (chron 34 to $38 \mathrm{Ma}$ ) into the South (Duncan and Storey, 1993). The oldest identified E-W magnetic anomalies of the India northern drift are dated Santonian (82 Ma, Royer et al., 1988), but incipient drift stage could have been initiated earlier, around 100 Ma according to Gibbons et al. (2013). This uncertainty is explained by the poor dating of the 118-84 Ma magnetic quiet zone.

Immediately south of our study area, at $18^{\circ} \mathrm{N}$, the seismic data published by Basu et al. (2010) shows the same NE-SE Cretaceous tilted blocks in the basement that could be interpreted as stretched continental crust. Southward the imprint of the $90^{\circ} \mathrm{E}$ ridge is erasing this rift fabric.

However, this transition from rift to drift is supported by the new global marine model from CryoSat-2 and Jason-1 data (Figure 1) and reveal the easternmost N-S transform faults related to the drift stage extend up to $13^{\circ} \mathrm{N}$, much farther North than the accepted boundary of Chron 34 as shown in Figure 1 (Sandwell et al., 2014). 
123 In the present state of our knowledge, we think NW-SE trending Gondwana rift structures

124 observed in the NE Bay of Bengal basin could be as young as $100 \mathrm{Ma}$. In conclusion, we suggest

125 the transition from Gondwana rifting and India oceanic spreading could have occurred around

126100 Ma or even before.

128 Interpretation of the multi-channel seismic lines acquired in the

129 northern part of the Bay of Bengal

130 We have collected MCS data offshore Myanmar in 2006 B2 cruise (Maurin and Rangin, 2009a,

$1312009 \mathrm{~b}$ ) (Figure 2) using a $4.5 \mathrm{~km}$ long streamer with a $3000 \mathrm{in}^{3}$ air gun source. Some of these

132 data were used in this study (Figure 2).

133 Late 2007-early 2008, we have collected new MCS data offshore Bangladesh. This B3 cruise was

134 conducted on the R/V Osprey Explorer using a $10.05 \mathrm{~km}$ long streamer with 804 channels,

135 towed at a water depth of $8 \mathrm{~m}$ and with a shooting interval of $50 \mathrm{~m}$. The seismic source was a

$1366180 \mathrm{in}^{3}$ tuned air gun array of 64 air guns towed at a depth of $8 \mathrm{~m} .3500 \mathrm{~km}$ of MCS data were

137 acquired (Figure 2).

138 Refraction data were acquired during the B3 cruise along three MCS profiles (Figure 3) and

139 results were recently published (Sibuet et al., 2016). Nine OBSs were deployed along each of the

140 profiles, with a 20-km distance between OBSs. This refraction experiment using OBSs from

141 Taiwan University and the air gun source of the ship was conducted during the acquisition of

142 three MCS lines, one across the shelf break (B3-5), and two parallel to the shelf break, one north

143 of it (B3-11) and one south of it (B3-02). The refraction processing was completed in the

144 IFREMER Center of Brest. We have used part of the seismic velocities resulting from this

145 refraction study to better constrain the seismic layers identified in the MCS lines. 
146 To complement the tectonic understanding of the northern Bengal basin, we have also used the

147 published works of Bastia and Radhakrishna (2012) and Nemcock et al. (2012) who have partly

148 interpreted GXT MCS lines located along the East coast of India (Figure 2).

149 Lines across the northern termination of the Bengal basin

150 The 2007 B3 survey was concentrated along and across the shelf break area between $20^{\circ}$ and

$15121^{\circ} \mathrm{N}$ (Figure 3). Two long seismic lines were also acquired along the west flank of the $90^{\circ} \mathrm{E}$

152 Ridge in the deepest part of the Bengal basin (Figure 2). The interpretation of the B3 seismic

153 lines is presented here and complemented by the interpretation of some other seismic lines

154 acquired during the 2006 B2 survey across the northernmost termination of the offshore Indo-

155 Burma Ranges (Figure 3).

\section{Seismic lines interpretation}

157 We here discuss the results and interpretation of the B3 E-W and NW-SE trending lines

158 complemented by some E-W trending B2 lines to illustrate the structure of the northernmost

159 deep Bengal Basin. Then, we will discuss the N-S trending lines across the Bengal shelf break.

160 Line B3-02 (Figure 4) shows the most complete dated seismic sequences correlated with the easternmost GXT ION MCS line of the Mahanadi basin published by Bastia and Radhakrishna

162 (2012). The total thickness of the Cenozoic sediments reaches $7.5 \mathrm{~s}$ TWT and was conformably deposited on a thin $(<1 \mathrm{~s}$ TWT) highly reflective seismic layer shown in green. This undisturbed

164 layer was deposited disconformably on the complex crustal basement. It is attributed to the

165 pelagic Latest Cretaceous-Paleocene sequence corresponding to the northern drift of India and

166 was continuously mapped down to $17^{\circ} \mathrm{N}$, all along the Bengal basin, blanketing the $90^{\circ} \mathrm{E}$ Ridge

167 basement (Maurin and Rangin, 2009a). At this latitude, the B2-01 line is calibrated with DSDP

168 drilling hole 217, indicating a Campanian-Maastrichian-Paleocene age for the pelagic sequence

169 (Figure 5). No structures were observed below the upper crust brittle layer identified here as

170 the lower crust. 
171 Using these data, we propose that the overlying Cenozoic sedimentation on line B3-02 started in

172 the late Paleocene-Eocene, at the time of the incipient collision of Greater India with Eurasia. The

173 top Oligocene was deposited on a relatively thin sequence of late Paleocene-Eocene sediments,

174 demonstrating that this basin was far away from the Himalayas and probably fed by eastward

175 India/Sunda collision in Myanmar. These Early Paleogene sediments were deposited extensively

176 along the eastern margin of the basin along the coast of Myanmar, particularly along the deep

177 channels present along the Arakan range, offshore Myanmar (Rangin et al., 2013).

178 A continuous and thin seismic sequence (less than $1 \mathrm{~s}$ TWT) is observed at the base of the thick

179 Cenozoic sequence, and was deposited disconformably on the underlying crust. This thin

180 undeformed seismic sequence was also deposited on the $90^{\circ} \mathrm{E}$ Ridge volcanic basement that

181 fringes the Myanmar continental margin down to $16^{\circ} \mathrm{N}$ (Maurin and Rangin, 2009a). At this

182 latitude (Figure 5), we were able to correlate the seismic sequence observed on lines B2-01 and

183 B2-15 with DSDP Leg 22 Hole 217 located southward on the ridge (Moore et al., 1974). At DSDP

184 Site 217, the drilled pelagic section is mainly formed by Campanian-Maastrichian cherts, nanno-

185 chalk and porcellanic limestone, all testifying a pelagic environment. Numerous blocks with the

186 same lithology (Globotruncana sp., porcellanic limestone) engulfed in debris flows present along

187 the southern side of the Arakan Range were observed and collected. These deformed and chaotic

188 debris flows were interpreted by Maurin and Rangin (2009a) as $90^{\circ}$ E Ridge fragments wrenched

189 and incorporated along the Sunda plate margin in southern Myanmar.

190 In the northernmost part of the Bay of Bengal, the topographic and gravity signature of the ridge

191 disappears rather completely (Figure 3). Here, the nature of acoustic basement imaged in Figure

1924 is formed by two seismic layers: an upper and a lower crustal seismic layers differentiated on

193 the refraction data (Sibuet et al., 2016), the Moho being located at around $13 \mathrm{~s}$ TWT (Figure 4).

194 Here, the upper brittle upper crust, with refraction velocities ranging from 4.7 to $5.5 \mathrm{~km} / \mathrm{s}$, is

195 marked by eastward dipping reflectors that could represent eastward dipping volcanic

196 reflectors or the shoulders of crustal tilted blocks with progressive sedimentary fanning during 
block tilting. We globally favor this later interpretation on the basis of the good axial correlation of these dipping reflectors showing a rather continuous NE-SW trend (Figures 6 and 7).

199 The upper crust layer lies on the thicker and opaque homogenous lower crust characterized by 5.5 to $7.7 \mathrm{~km} / \mathrm{s}$ refraction velocities. These crustal velocities are too low for an oceanic basin floor and are interpreted as thinned continental crust intruded by volcanics (Sibuet et al., 2016).

202 When transformed in depth, the thickness of the two crustal layers is $15 \mathrm{~km}$ suggesting the 203 presence of a thinned continental crust formed during the crustal stretching associated with the 204 Gondwana fragmentation.

205 Previously published data show that the crust was oceanic beneath the northern BoB. 206 However, these results were not reliable as the sediment thickness is too large (Curray, 2071994 ; Verma and Mukhopadhyay, 1977 and Uddin and Lundberg, 2004). SIbuet et al. 208 (2016) refraction results clearly contradict this view. Their results do not fit also the velocity trends of the North Atlantic volcanic margins as discussed by Talwani et al. 210 (2017). This view is also supported by deep seismic refraction and reflection profiles 211 acquired across the Hatton bank, which show that the melt is intruded into the lower 212 thinned continental crust as sills, which cross-cut the continental fabric, rather than as 213 an 'underplate' of 100 per cent melt, as it was often assumed in the past (White et al., 214 2008). Therefore, the crust of the northern BoB is thinned continental crust with 215 intruded volcanics wth a possibility that the high lower crustal velocity might be due to 216 the presence of sills linked to the passage of the Kerguelen hot spot after the continental 217 rifting of the northern $\mathrm{BoB}$.

218 The west facing normal faults bounding these tilted blocks are difficult to image on our seismic 219 data but lines B3-14 and B3-02 (Figure 6) also reveal the presence of NE-SW trending faults 220 bounding the dipping reflectors. The correlation between these tilted blocks across the whole 221 studied area confirms this interpretation (Figure 7). The density of B3 seismic lines is sufficient 
222 to support the hypothesis that these NE-SW rifting trends were created by NW-SE continental

223 crustal extension simultaneously with the occurrence of a LIP volcanism. The major volcanic

224 centers identified in our survey are located along some of these major fault traces suggesting

225 volcanism and faulting are intimately linked during the continental extension processes.

226 A similar highly faulted brittle crust basement was evidenced offshore Myanmar by Basu et al.

227 (2010), immediately south of our study area, between $17.5^{\circ} \mathrm{N}$ and $19^{\circ} \mathrm{N}$. From their seismic data,

228 half-grabens affecting the northernmost part of the $90^{\circ} \mathrm{E}$ Ridge were described. Grabens are

229 filled by synrift clastic sediments indicating potential reservoir plays. This fractured basement is

230 disconformably covered by a thin layer similar to our Late Cretaceous-Paleocene layer. In the

231 same area, Lines B2-11 and B2-02 (Figure 2) reveal a similar geometry on top of the ridge

232 (Maurin and Rangin, 2009a). We were able to trace the ridge structural basement fracturation

233 between $14^{\circ} \mathrm{N}$ and $15^{\circ} \mathrm{N}$, in the Coco Channel area located along the maritime border with India

234 (Line B2-15, Figure 2). We conclude that the highly fractured Mesozoic Bengal basin basement

235 disconformably covered by the pelagic Late Cretaceous sediments extends all along the

236 Myanmar coast from Bangladesh to Andaman Islands.

A synthetic cross-section across the northern Bengal basin

239 On the basis of previous observations, a synthetic cross-section of the northern Bengal basin

240 was built (Figure 8). We think the N-W facing normal fault system affecting the thinned Bay of

241 Bengal continental crust in its western part, is the conjugated passive margin for the basins

242 developed along the Indian eastern coast showing east facing normal faults. The Mahanadi basin

243 is clearly N-E trending as well as the facing west Bengal basin in our study area, and most of this

244 narrow basin is floored by thin continental crust affected major S-E facing detachments (Nemcok 245 et al., 2013) and blanketed by thick Mesozoic and Cenozoic sediments. 
In this synthetic cross-section, the eastern part of the basin on the Myanmar side is much wider than its counterpart in the Mahanadi basin, suggesting an asymmetric rift geometry probably created by simple shear, a classical model for continental crust extension (Wernicke, 1985). No oceanic crust has been clearly emplaced in the axis of this asymmetric rift that fits the deepest part of the northern Bengal basin in the S-W prolongation of the "Swatch no Ground" canyon. Flat reflectors covered by Late Cretaceous sediments are interpreted by Nemcok (2013) as mantle domes tops and oceanic crust, with a well imaged Moho. We interpret this narrow rift axis segment as the site of mantle dome exhumation only at the axis of this continental rift axis. In this NW-SE synthetic cross-section, the asymmetric northern Bengal rift is bordered eastward by the $90^{\circ} \mathrm{E}$ Ridge. No strike-slip faults have been detected along the transect between the East India Coast and the $90^{\circ} \mathrm{E}$ Ridge, suggesting the whole rift was drifted without internal deformation. Major active strike-slip faults are present eastward of the $90^{\circ} \mathrm{E}$ ridge along its

258 boundary with the Arakan Belt (Maurin et al., 2009a and b; Rangin et al., 2013). The Arakan Belt 259 is a complex system formed by distinct amalgamated terranes to the Sunda plate, such as the 260 Burma continental block. This complex Early Paleocene-Eocene India/Sunda collision zone is 261 illustrated in the right hand-side of the section.

Then, we assume that the northern Bengal basin floored by attenuated continental crust was not deformed since the end of the Gondwana rifting and was preserved in its structural integrity

264 since then. The Bay of Bengal crust at the latitude of our study appears as rigid. It was never 265 affected by significant post-rift and post-drift deformation at the latitude of our study. This suggests the hydrocarbon potential of this rift sealed by the continuous syn-drift pelagic Late

267 Cretaceous Paleocene sequence is large. The presence of intense heat flow affecting this thin 268 continental rift zone during stretching of the continental crust was enhanced by the volcanic intrusion of the Kerguelen hot spot volcanism during the fragmentation of Gondwanaland. 
272 The B3 N-S trending seismic lines crosscut the Bengal delta fan, which trends constantly E-W

273 over $200 \mathrm{~km}$, from the Swatch No Ground Canyon into the west, to the Indo-Burma ranges into

274 the east (Figures 2 and 3). From West to East, the E-W linearly prograding delta front was

275 surveyed along the N-S trending lines B3-01, B3-10, B3-09, B3-09, B3-06, B3-05 B3-04, B3-03

276 and B3-15 (Figure 3). The shelf break appears to be perfectly aligned along these sections.

277 Line B3-05 (Figure 9) is representative of the numerous N-S transects across the recent

278 southward progradation of the Ganges delta as well as the structure of the thinned continental

279 crust at depth. It is also one of the lines selected for the seismic refraction experiment. Below the

280 sedimentary pile, the southern part of this profile shows a small high interpreted as a pre-Late

281 Cretaceous volcano probably built during the Bengal basin Mesozoic rifting phase. It could be

282 one of the numerous LIP volcano injected through the thinned continental crust. Deep reflectors

283 of the upper continental crust are gently flexured below the volcano, indicating the volcano load

284 was emplaced after the thinning of the continental crust.

285 On the time section, the Late Cretaceous-Paleocene thin layer (3 in Figure 9) was clearly

286 deposited disconformably on the deeper sequences. Reflectors of sequence 4 are gently folded

287 just below the present-day delta front. These reflectors are similar to those observed northward

288 in the Sylhet basin or westward, along the east India continental margin and could represent a

289 rather thick Mesozoic Gondwana syn-rift sedimentary unit.

290 Northward, the upper Neogene and Quaternary sedimentary sequence 1 clearly shows the delta

291 front southward progradation, where at depth, the Paleogene-Early Neogene and Late

292 Cretaceous sequence 3 is gently flexured. All these sediments appear to onlap disconformably a

293 basement high (delta front high) exaggerated by the seismic pull-up on this time section.

294 However, when the section was flattened at the base of sequence 1 the basement high is still

295 observable. The pull-up effect on this time-section does not also entirely explain the gentle

296 folding affecting sequence 2. This deep rooted folding could be interpreted as recent, and could

297 explain the $200 \mathrm{~km}$ E-W trending delta shelf break. This linear delta front could be guided at 
depth by an active E-W trending crustal uplift comparable to the Shillong plateau uplifted since a

299 longer time.

300

301

302

303

304

305

306

307

308

However, onlaps of the Cretaceous sequence 4 on this delta front high suggest that this basement high existed before its recent tectonic reactivation. This large anticline could be inherited from the Precambrian E-W trending structures present in the Indian craton, in the Singhum area (Geological map of India). It confirms that the crust below the delta front and the onshore Bengal basin is continental. We propose this tectonic reactivation is coeval with the Shillong plateau uplift initiated around 5 Ma (Bilham and England, 2001). We think that both the EW alignment of the recent delta shelf break above the delta basement high at depth as well as the Shillong plateau uplift are controlled by the tectonic reactivation of old Indian craton structures.

In Figure 11, the Bay of Bengal extends northward below the Bengal onshore delta. Westward, it is bounded east of the Indian Precambrian craton by the so-called "Hinge zone" (Uddin and Lundberg, 2004) characterized by Nummulites bearing Eocene shelf limestone (Johnson and Alam, 1991). We have sampled the same neritic limestone on the Myanmar side in Ramree (at $19^{\circ} \mathrm{N}$ ) and Buruanga Islands (at $20^{\circ} \mathrm{N}$ ) along the Kaladan shear zone running along the outer Indo-Burma belt (Maurin and Rangin, 2009b). A possible interpretation is that the Bay of Bengal and the Bengal basin northward now bordered eastward by right-lateral strike-slip fault belt along the Indo-Burma Ranges, was closing axially "en doigt de gant" during the Mesozoic, before the India/Sunda collision and dextral wrenching. In this hypothesis, the paleogeographic closure of the Bay of Bengal and its onshore extension in the Bengal Basin was acquired during the Mesozoic rifting of Gondwana as shown in the simple sketch of Figure 12. Thus, the studied area (marked by a square) could have been located at the northern termination of a larger rift basin opened between the Indian craton and the Elan Bank continental sliver. The basin was filled by Mesozoic clastic sediments injected by volcanism of the large LIP of the Kerguelen hotspot (KHS on Figure 12). This hot spot volcanism crops out in the Rajmahal (RJT) and Sylhet traps north of 
the present Bengal basin drifted away from Gondwanaland. In the mid-Cretaceous time, the Bengal basin was progressively detached from Antarctica and Australia. The drifted part of the Bay of Bengal attached to India was sealed by pelagic sediments during its Late Cretaceous and Paleocene drifting migration toward Eurasia. The Bay of Bengal is considered as a new challenge for hydrocarbon exploration, the source rocks being probably located below the Late Cretaceous unconformity.

\section{Conclusions}

This study of MCS data in the northernmost part of the Bay of Bengal reveals the presence of a continental rift formed during the fragmentation of Gondwana, before the Late Cretaceous. The refraction data collected during the same cruise indicate that the crust is of continental origin and strongly thinned (15-km thick) during the Gondwana rifting. Offshore Bangladesh, the SE flank of this rift zone was only imaged in our study area. This western rift flank is present along the eastern coast of India but is here very narrow, indicating a strongly asymmetric continental rift created by simple shear extension mechanism in the Gondwana continental crust. During the Bay of Bengal opening, some of the rift normal faults were injected by pre-late Cretaceous LIP volcanism. We suggest this volcanism is part of the Rajmahal and Sylhet volcanic traps, considered as drifted fragments of the Kerguelen LIP province, cropping out immediately north of the study area and injected in the thick continental crust of the Indian craton. We think the northern Bay of Bengal attenuated crust was formed immediately southward of the drifted Rajmahal and Sylhet traps LIP volcanism, detached during the mid-Cretaceous from its mother land, the Kerguelen hot spot plateau in Gondwana.

The northern termination of the Bay of Bengal crust extends very far to the north, below the onshore Bengal delta, where it was interpreted as oceanic crust (Uddin and Lunberg, 2004). We believe this crust is here attenuated continental crust, flexuring below the uplifted continental Shillong plateau. 
Eastward, this basin disappears below the wrenched fold and thrust belt of the Indo-Burma

Ranges. We interpret this wedge as related to combined effect of N-S dextral wrenching along the India/Sunda plates boundary and S-W directed East Himalaya crustal flow of the East Himalaya syntaxis, and not to an active subduction of the Bay of Bengal below Sunda.

Consequently the northern Indo-Burma wedge is just a wide WSW directed Neogene gravitational flow and not an active subduction zone (Rangin et al., 2013). This implies the northern paleogeographic closure of the Bay of Bengal floored by attenuated continental crust was not significantly modified, but just blanketed by this sedimentary East Himalaya sedimentary and crustal flow related to the East Tibetan plateau collapse.

\section{Acknowledgments}

We thanks all the scientific team involved in this 2007 B3 cruise but also the Bangladesh Navy, which provides us full support at sea, as well as the Bengali Government particularly Dr. Nazrul Islam, who facilitated the necessary clearances for this cruise. The seismic processing of B3 lines was performed by CGG/Total in Pau (France). We thanks Total Exploration and Production in Paris for the financial support of this cruise and the numerous discussions with their technical team.

\section{References}

Alam M., Alam M. M., Curray J. R., Chowdhury M. L. R. and Gani M. R., 2003. An overview of the sedimentary geology of the Bengal Basin in relation to the regional tectonic framework and basin-fill history. Sedimentary Geology, 155(3), 179-208.

Basu P., Verma R., Pal R. and Vishwanah K., 2010. Deep waters of the Rakhine Basin - A new Frontier? $8^{\text {th }}$ Biennal Int. Conf. and exposition on petroleum geophysics, extended abstract pp 160-167. 
Banerjee B., Sengupta B. J. and Banerjee P. K., 1995. Signals of Barremian (116 Ma) or younger oceanic crust beneath the Bay of Bengal along $14^{\circ} \mathrm{N}$ latitude between $81^{\circ} \mathrm{E}$ and $93^{\circ}$ E. Marine geology, 128(1), 17-23.

Bastia R. and Radhakrishna, M., 2012. Basin evolution and petroleum prospectively of the continental margins of India (Vol. 59) Elsevier ISBN 978-0-444-53602-4, 409p.

Bilham R. and England P., 2001. Plateau Pop Up during the 1897 Assam Earthquake. Nature 410, 806-809.

Brune J.N and Singh D.D. 1986. Continent-like crustal thickness beneath the bay of Bengal sediments. Bull. Of the Seismological Society of America, 76, 191-203.

Coffin M. F., Pringle M. S., Duncan R. A., Gladczenko T. P., Storey M., Müller R. D. and Gahagan L. A, 2002. Kerguelen hotspot magma output since 130 Ma. Journal of Petrology, 43(7), 1121-1137.

Curray J. R., Emmel F. J., Moore D. G. and Raitt R. W., 1982. Structure, tectonics, and geological history of the northeastern Indian Ocean in: Nairn, A.E.M., Stehli, F.G.(Eds.), The oceanic basins and margins: The Indian Ocean, 6. Plenium Press, New York. pp. 399-450.

Curray J. R. and Munasinghe T., 1991. Origin of the Rajmahal Traps and the $85^{\circ}$ E Ridge: Preliminary reconstructions of the trace of the Crozet hotspot. Geology, 19 (12), 12371240.

Curray, J.R., 1994. Sediment volume and mass beneath the Bay of bengal. Earth Planet. Sci. Lett. 125 (1-4), 371-383.

Desa M. A., Ramana M. V., Ramprasad T., Anuradha M., Lall M. V. and Kumar B. J. P., 2013. Geophysical signatures over and around the northern segment of the $85^{\circ} \mathrm{E}$ Ridge, Mahanadi offshore, Eastern Continental Margin of India: Tectonic implications. Journal of Asian Earth Sciences, 73, 460-472.

Duncan R. A. and Storey M., 1993. The life cycle of Indian Ocean hotspots. Synthesis of Results from Scientific Drilling in the Indian Ocean, 91-103. Am. Geophys. Union, Doi 10.1029/GM070P0091.

Gibbons A. D., Whittaker J. M., and Muller R. D., 2013. The breakup of East Gondwana: Assimilating constraints from Cretaceous ocean basins around India into a best-fit tectonic model.J. Geophys. Res., 118, 808-822.

Grevemeyer I., Kaul N., Villinger H. and Weigel W., 1999. Hydrothermal activity and the evolution of the seismic properties of upper oceanic crust. J. Geophys. Res., 104(B3), 5069-5079.

Jhonson S. Y. and Alam N., 1991. Sedimentation and tectonics of the Sylhet trough, Bangladesh, GSA Bull., 103, 1513-1527. 
Kent R. W., Pringle M. S., Muller R. D., Saunders A. D. and Ghose N. C., 2002. 40Ar/39Ar geochronology of the Rajmahal basalts, India, and their relationship to the Kerguelen Plateau. Journal of Petrology, 43(7), 1141-1153.

Klootwijk C. T., Gee J. S., Peirce J. W. and Smith G. M., 1991. Constraints on the India-Asia convergence: Paleomagnetic results from Ninetyeast Ridge. In Proc. ODP Sci. Results, Vol. 121, pp. 777-882.

Le Pichon X. and Heirtzler J. R., 1968. Magnetic anomalies in the Indian Ocean and seafloor spreading. J. Geophys. Res., 73(6), 2101-2117.

Maurin T. and Rangin C., 2009a. Impact of the $90^{\circ} \mathrm{E}$ Ridge at the Indo-Burmese subduction zone imaged from deep seismic reflection data. Marine Geology, 266(1), 143155.

Maurin T. and Rangin C., 2009b. Structure and kinematics of the Indo-Burmese Wedge: Recent and fast growth of the outer wedge. Tectonics, 28(2). DOI: 10.1029/2008TC002276.

Moore D. G., Curray J. R., Raitt R. W. and Emmel F. J., 1974. Stratigraphic-seismic section correlations and implications to Bengal Fan history. In von der Borch C. C., Sclater J. C. et al. (Eds.), Initial reports of the Deep Sea Drilling Project, Leg 22 (pp. 403-412).

Washington, DC: US Government Printing Office.

Mukhopadhyay M. and Krishna M. R., 1991. Gravity field and deep structure of the Bengal Fan and its surrounding continental margins, northeast Indian Ocean. Tectonophysics, 186(3), 365-386.

Nemčok M., Sinha S. T., Stuart C. J., Welker C., Choudhuri M., Sharma S. P. and Venkatraman S., 2013. East Indian margin evolution and crustal architecture: Integration of deep reflection seismic interpretation and gravity modeling. Geological Society, London, Special Publications, 369(1), 477-496.

Rao D. G., Krishna K. S. and Sar D., 1997. Crustal evolution and sedimentation history of the Bay of Bengal since the Cretaceous. J. Geophys. Res., 102(B8), 17747-17768.

Ramana M. V., Nair R. R., Sarma K. V. L. N. S. Ramprasad T., Krishna K. S., Subrahmanyam V. and Sekhar D. C., 1994. Mesozoic anomalies in the Bay of Bengal. Earth Planet. Sci. Letters, 121(3), 469-475.

Rangin C., Maurin T. and Masson F., 2013. Combined effects of Eurasia/Sunda oblique convergence and East-Tibetan crustal flow on the active tectonics of Burma. Journal of Asian Earth Sciences, 76, 185-194.

Royer J. Y., Patriat P., Bergh H. W. and Scotese C. R., 1988. Evolution of the Southwest Indian Ridge from the Late Cretaceous (anomaly 34) to the Middle Eocene (anomaly 20). Tectonophysics, 155(1), 235-260. 
451

452

453

454

455

456

457

458

459

460

461

462

463

464

465

466

467

468

469

470

471

472

473

474

475

476

477

478

479

480

481

482

483

484

Sandwell D. T., Muller R.D., Smith W.H.F., Garcia E. and Francis R., 2014. New global marine model from CryoSat- 2 and Jason-1 reveals buried tectonic structure. Science Research Report 346, 6205, 65-67.

Sclater J. G. and Fisher R. L., 1974. Evolution of the east Central Indian Ocean, with emphasis on the tectonic setting of the Ninetyeast Ridge. Geological Society of America Bulletin, 85(5), 683-702.

Sibuet J.-C., Klingelhoefer F., Huang Y.-P., Yeh Y.-C., Rangin C., Lee C.-S. and Hsu S.-K., 2016, submitted. Thinned continental crust intruded by volcanics beneath the northern Bay of Bengal. Mar. Pet. Geol., 77, 471-486.

Subrahmanyam C., Thakur, N.K., Gangadhara Rao, T.,Ramana, M.V., Subrrahmanyam, V.,1999. Tectonics of the Bay of Bengal, northeastern Indian Ocean: new insights from satellite-derived gravity and shipborne geophysical data. Earth and Planetary Science Letters 171, 237-251.

Talwani, M., Krishna, K.S., Ismaiel, M., Desa, M. A., 2017. Comment on a paper by Sibuet et al. (2016) entitled "Thinned continental crust intruded by volcanics beneath the northern Bay of Bengal”. Mar. Pet. Geol., http://dx.doi.org/10.1016/j.marpetgeo.2016.12.009.

Uddin A., Lunberg N., 2004. Miocene sedimentation and subsidence during continentcontinent collision Bengal Basin Bangladesh. Sedimentary Geology, 164 (1-2), 131-146.

Verma, R.K., Mukhopadhyay, M., 1977. An analysis of the gravity field in Northeastern India. Tectonophysics 42 (2-4), 283-317.

Wernicke B., 1985. Uniform-sense normal simple shear of the continental lithosphere. Canadian Journal of Earth Sciences, 22, 108-125.

White, R. S., Smith, L. K., Roberts, A. W., Christie, P. A. F., Kusznir, N. J. and the rest of the iSIMM Team, 2008. Lower-crustal intrusion on the North Atlantic continental margin. Nature, 452, 460-464.

\section{Figure captions}

Figure 1: Transition from rifting to spreading in the Bengal basin plotted on Mercator projected 1-min satellite derived free-air gravity field map (Sandwell et al., 2014). Chron 34 (Santonian in red) and younger magnetic anomalies southward fit the steady state drift of India and attached Bengal basin. The satellite image reveals deep buried 
485

486

487

488

489

490

491

492

493

494

495

496

497

498

499

500

501

502

503

504

505

506

507

structures in this basin: Some of the N-S transform faults can be traced up to $13^{\circ} \mathrm{N}$, much farther than chron 34, suggesting India drifting was initiated much earlier, during the Mid-Cretaceous. In the northernmost part of this basin, NE-SW trending structures can be detected East and South of the study area, and can be part of the Gondwana continental rifting stage.

Old magnetic lineaments proposed by Gibbons et al. (2014) are also plotted on the figure. The frame indicates the study area discussed in this paper.

Stars indicate DSDP and ODP drill sites: DSDP 217, ODP 758 and DSDP 216 from N to S respectively.

Figure 2: Multi-channel reflection seismic data recently acquired in the northern Bengal basin. Our seismic lines acquired in 2006 (labeled B2) and 2007 (labeled B3) are in red and GXT lines (acquired by ION GXT and ONGC) partially published by Desa et al. (2013) and Nemcock et al. (2013) along the coast of India are in blue. Track-lines are plotted on the GEBCO shaded bathymetry map.

Figure 3: B3 cruise seismic survey at the northern termination of the Bengal basin offshore Bangladesh. Acquired seismic lines are plotted on the free-air gravity map (Sandwell et al., 2014). Refraction data were acquired along lines B3-02, B3-05 and B311 (Sibuet et al., 2016). The north Indo-Burma ranges fold belt anticlines are plotted in red.

Figure 4: Top: Line drawing interpretation of Line B3-02. Cenozoic sediments (Late Paleogene to present-day) were dated by correlation with the East Indian passive margin dated sequences. The Cenozoic sediments overlain a thin but highly reflective seismic sequence attributed to the Late Cretaceous. This highly reflective sequence 
508

could represent the condensed pelagic sequence deposited during drifting of India with the attached Bengal basin. The drifted sequence was deposited disconformably on tilted fault blocks dissecting Early Cretaceous (or older) deposited sediments during the rifting phase of Gondwana. Bottom: Corresponding refraction time-section with distinct thinned continental crustal layers obtained by refraction (Sibuet et al., 2016). Two main crustal layers were identified, a brittle upper crust and a lower crust with a total thickness of $15 \mathrm{~km}$.

Figure 5: Correlation between Line B2-01 offshore south Arakan in Myanmar and Drill Site 217 (DSDP Leg 22, Moore et al., 1974). The high reflective layer observed on the B201 line crossing the $90^{\circ} \mathrm{E}$ Ridge can be precisely dated Campanian, Maastrichian and Paleocene.

Figure 6: Correlation of tilted blocks on lines B3-14, B3-02 and B2-11 supporting the $\mathrm{N} 50^{\circ} \mathrm{E}$ trend of the Northern Bengal crust fabric.

Figure 7: $\mathrm{N} 50^{\circ} \mathrm{E}$ trending tectonic fabric of this area plotted on free-air gravity anomaly map. Dominant NE-SW trending listric normal faults are shown in green as well as the northernmost termination of the $90^{\circ}$ E Ridge discussed by Maurin and Rangin (2009a).

The $\mathrm{N} 50^{\circ} \mathrm{W}$ Arakan fold and thrust belt front is marked by a strong positive anomaly. This gravity collapsed fold belt extends westward along the E-W trending Bengal delta shelf break (Maurin and Rangin, 2009b). Free-air gravity anomaly map is used as background. Tilted sequences are dipping SW and are truncated by the following normal fault (barbed green lines). Main volcanic centers are shown in blue and were injected along some normal faults. 
530 Figure 8: NW-SE trending synthetic cross-section of the northern Bay of Bengal. This 531 section was drawn perpendicularly to the NE-SW extension direction of the basin. The 532 N-E part of this section represents the observed data in our study area. In this cross533 section, we have used the B2-11 and B3-02 time sections transformed to depth using 534 refraction data. To the west, the synthetic section of the Mahanadi basin was built 535 following Bastia and Radhakrishna (2012), Desa et al. (2013) and Nemcok et al. (2013). 536 The onshore Myanmar cross-section was simplified from Rangin et al. (2013). Location 537 of cross-section is plotted on the Bengal basement map insert (s. TWT).

538 Figure 9: Line B3-05 interpretation showing the recent (late Miocene to present) 539 progradation of the Delta front (1) and the Paleogene-Lower Neogene (2) gently folded 540 with the late Cretaceous sediments (3) just below the delta progradation. The E-W 541 basement delta front high (4) cannot be only explained by a pull-up artifact. Location of 542 Line B3-05 on Figure 3. * indicates mass-sedimentary flows. m=multiples.

543 Figure 10: B3 lines across the Delta shelf Break. These profiles acquired along the $544300 \mathrm{~km}$ long E-W shelf break perfectly fits the crustal uplift located at depth and the 545 delta front above. Location of seismic lines in Figure 3. The N-S line B3-01 is located into 546 the west and B2-03 into the east.

547 Figure 11: Northern paleogeographic closure of the Bengal basin onshore Bangladesh.

548 Main active structures are shown in red. Simplified N-S cross-section along the axial 549 termination of the Bengal basin. The map and the simplified cross-section below are 550 modified from Uddin and Lunberg (2004).

551 Figure 12: Tentative reconstruction of the Bay of Bengal rift zone before detachment 552 and northward drift of India. KHS: Kerguelen hot spot, RJT: Rajmahal LIP traps, ST: 
553 Silhet LIP traps, BR: Broken Ridge. The green line is the speculated fracture zone along

554 Elan Bank. The detachement of drifted India is supposed to be the future trace of the

$55590^{\circ} \mathrm{E}$ Ridge. KHS is supposed to be placed along the oceanic Enderby basin (shown in

556 pink). The red star is the speculated India-Bengal /Eurasia rotation pole during the

557 incipient India-Bengal drifting. 


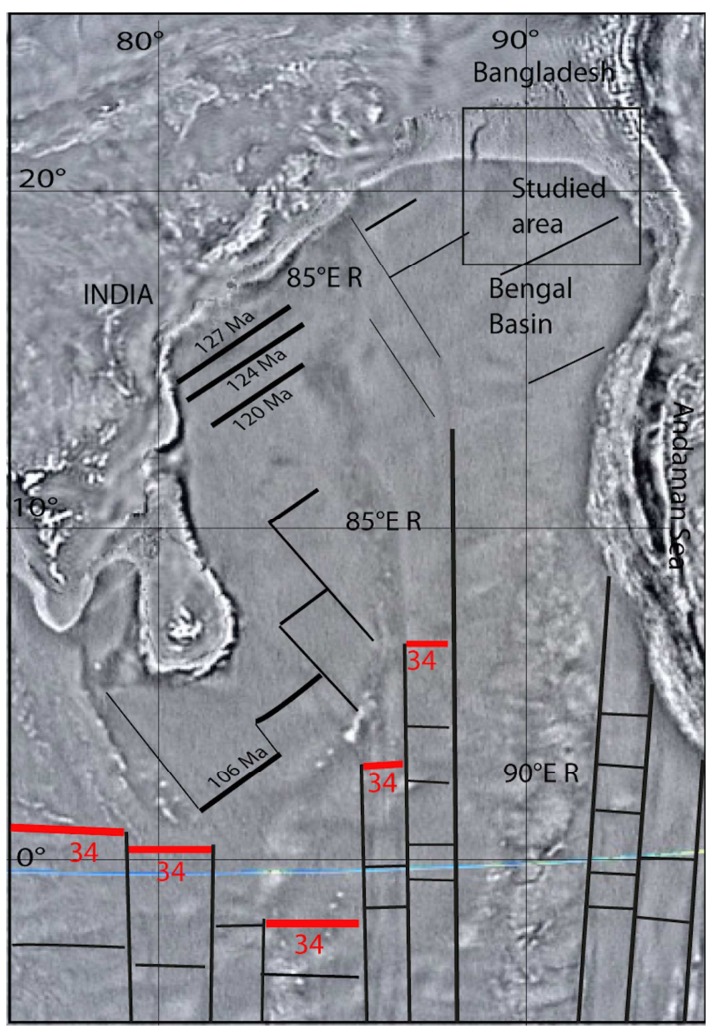




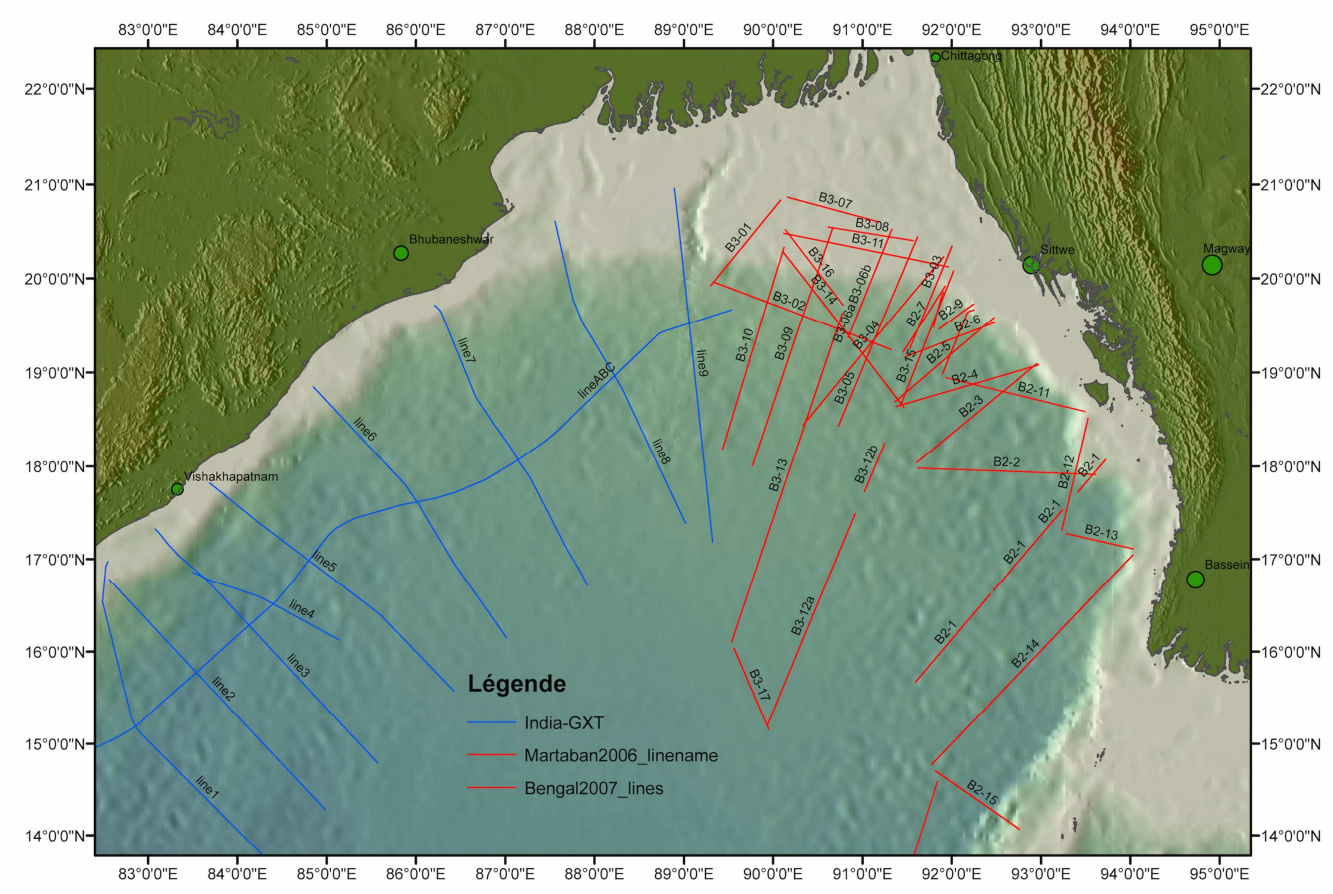




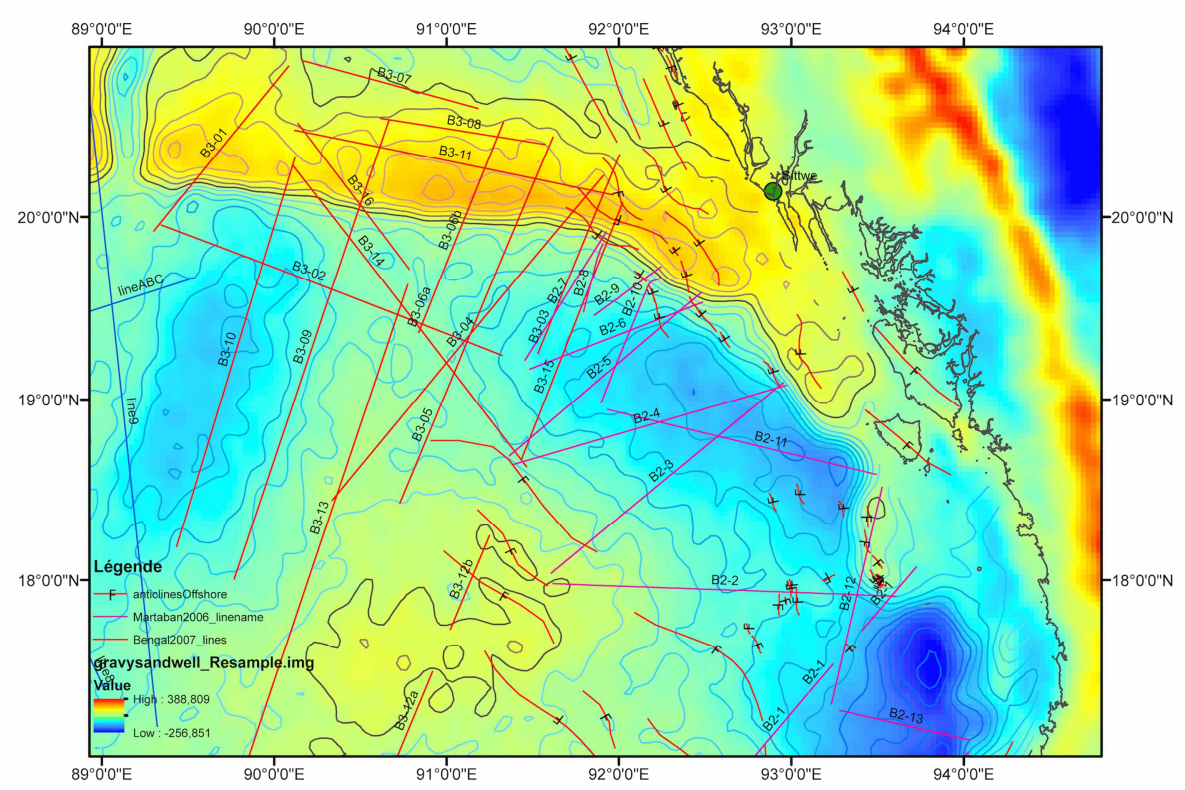



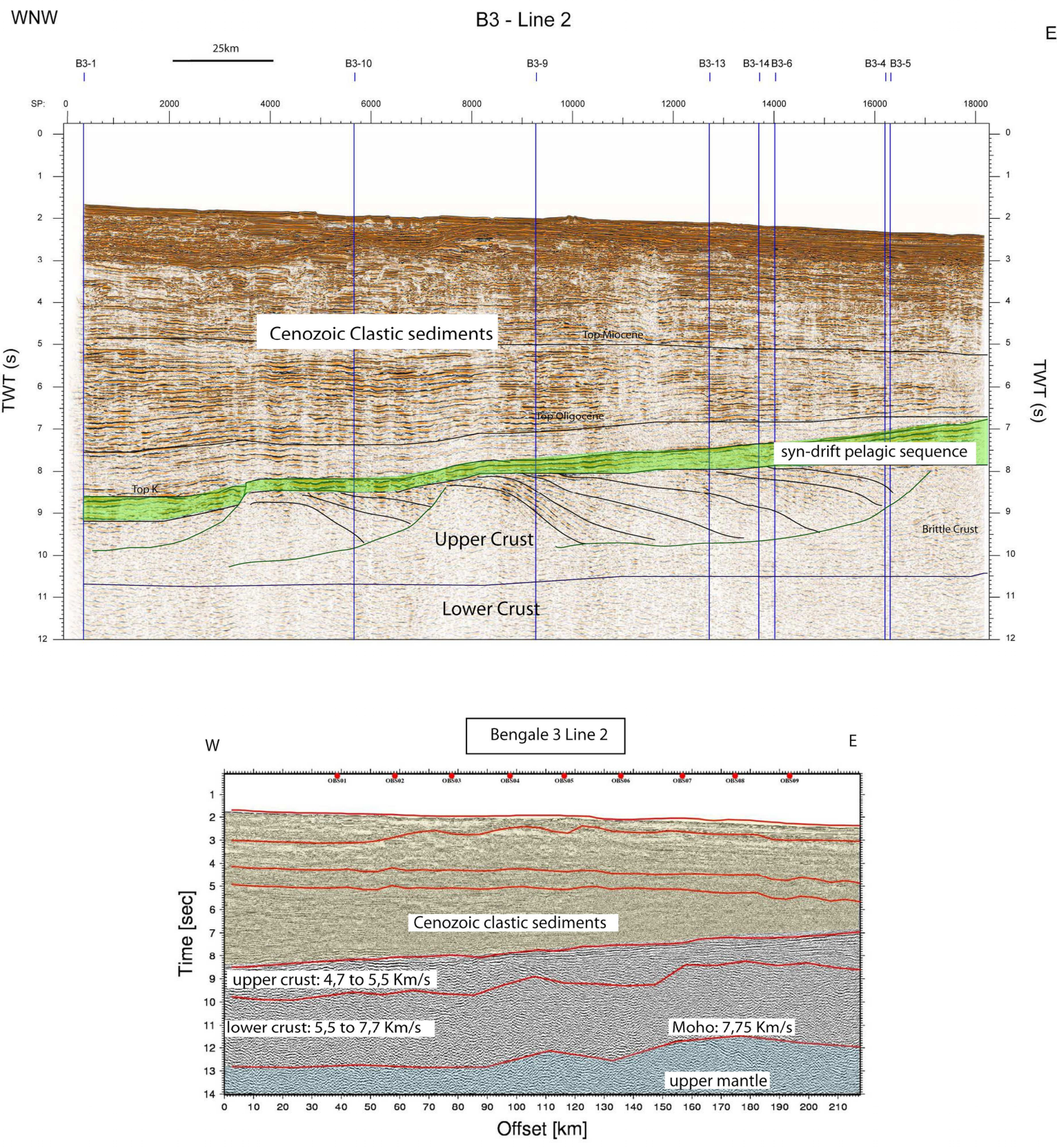
SITE 217

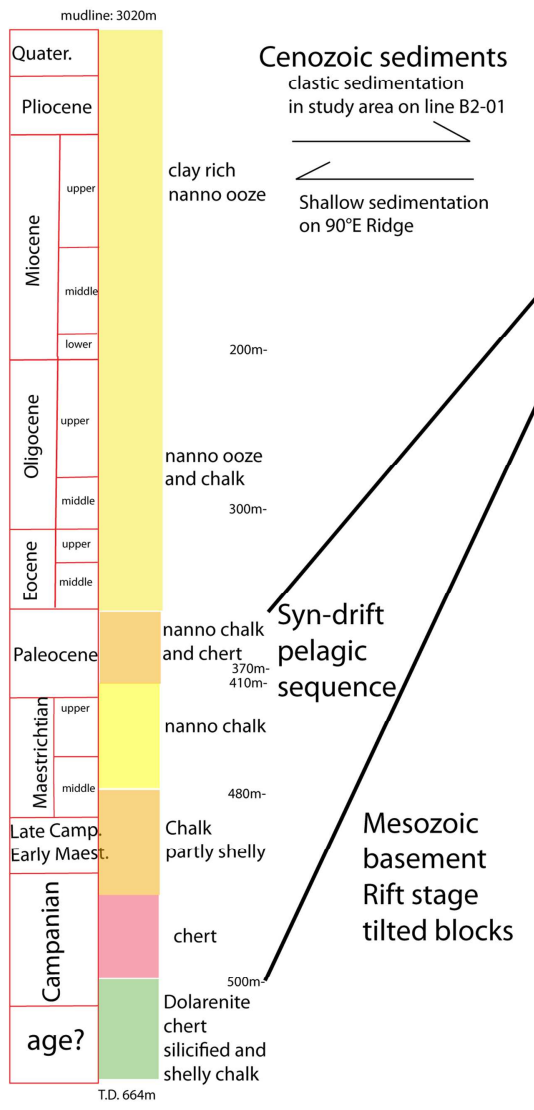

Extract line B2-01 South Arakan offshore

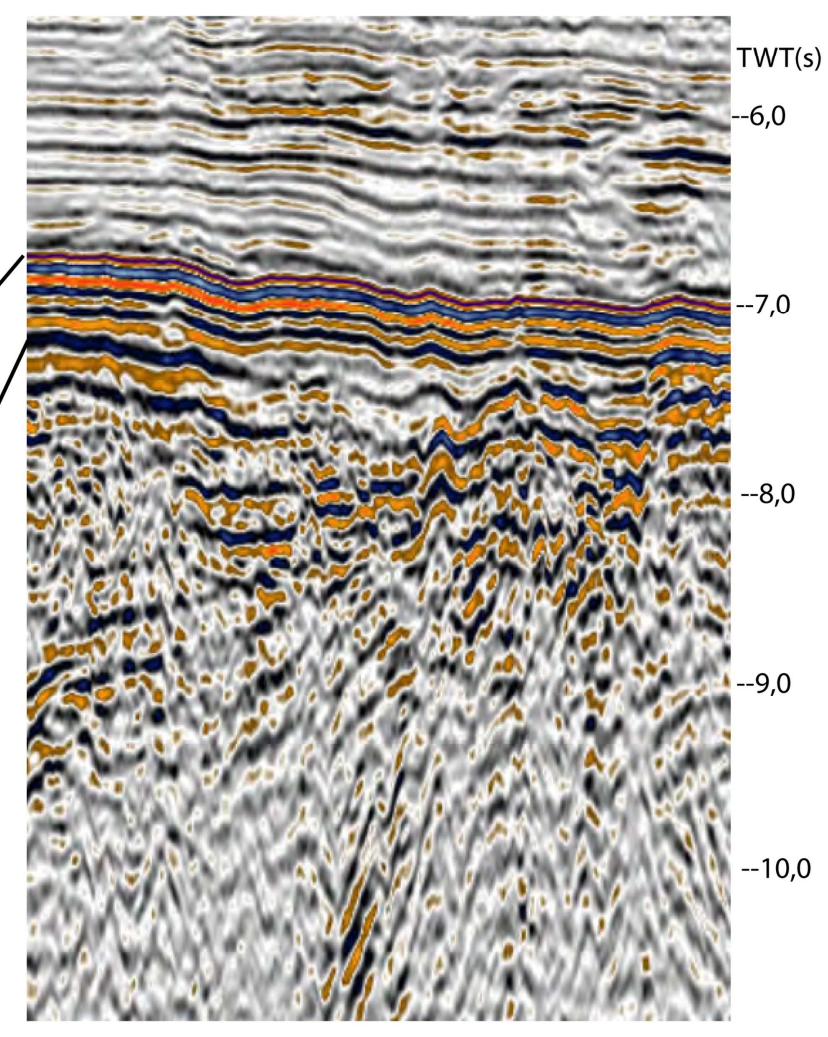



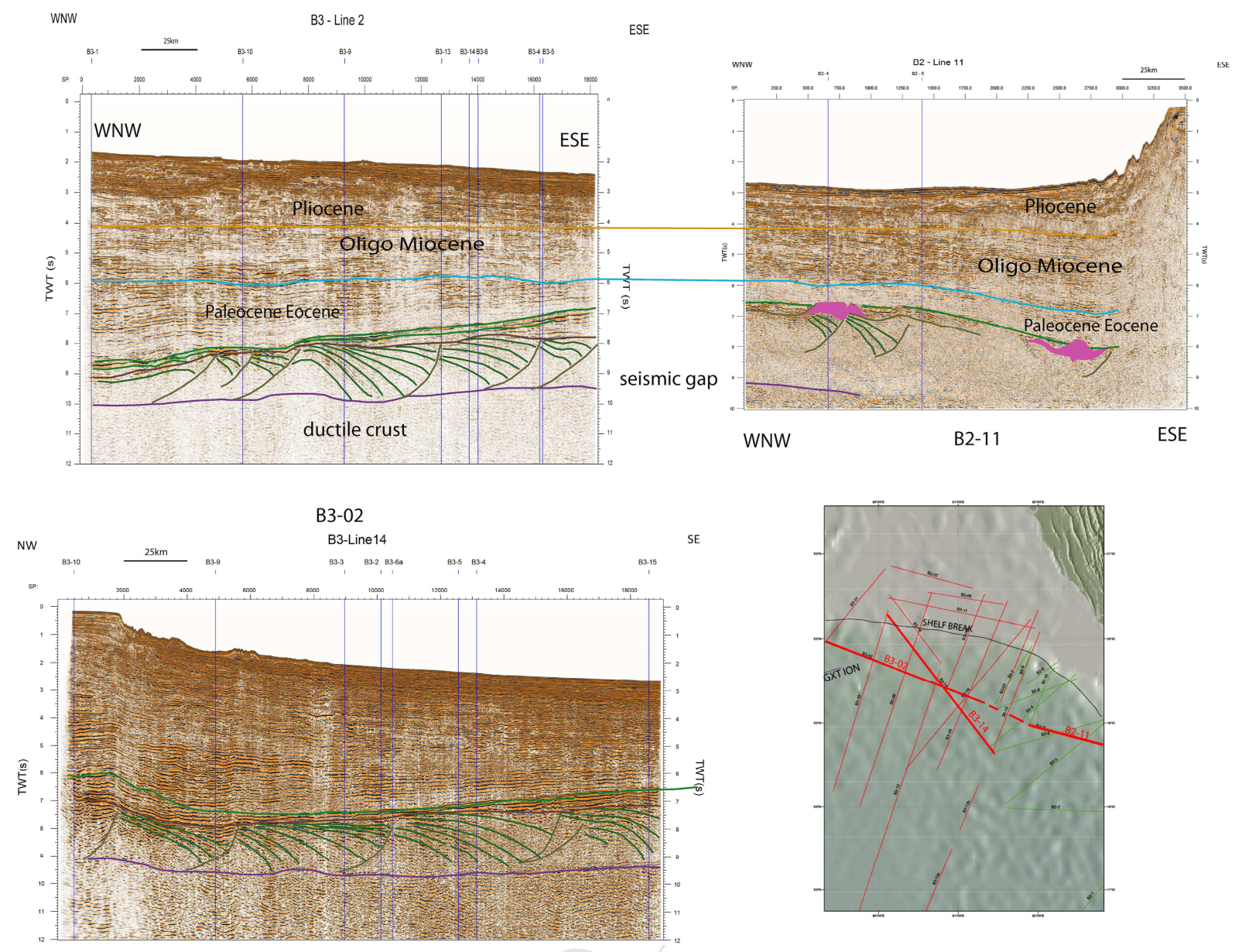


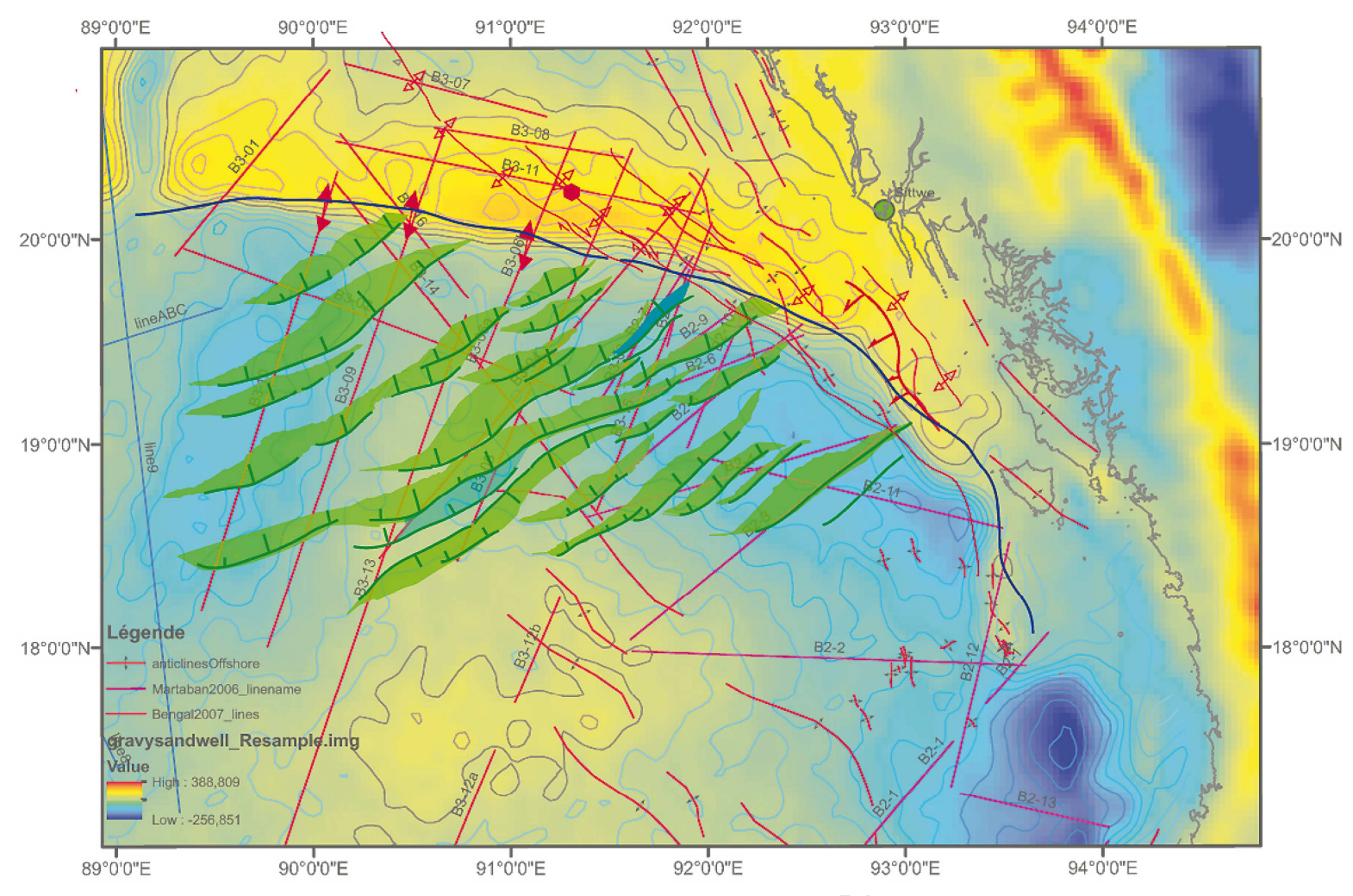


w

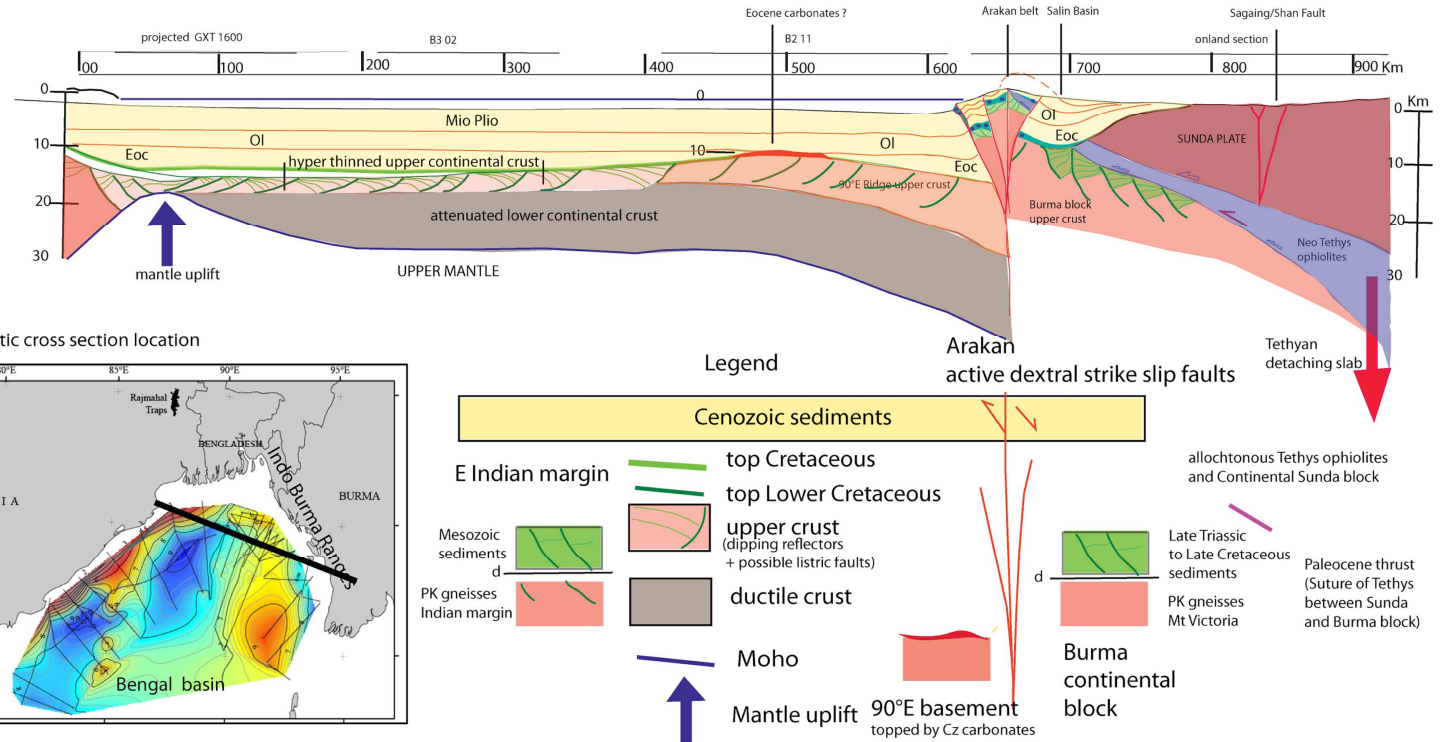

Bengal west passive margin

deep Bengal basin

Bengal East passive margin 


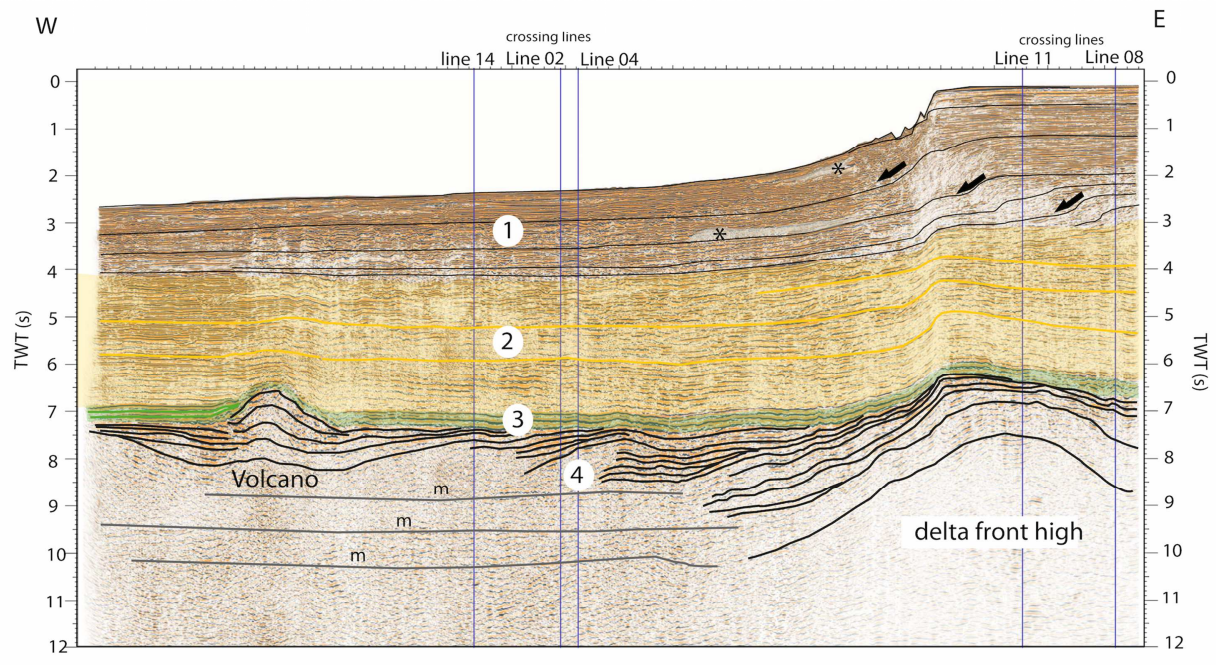




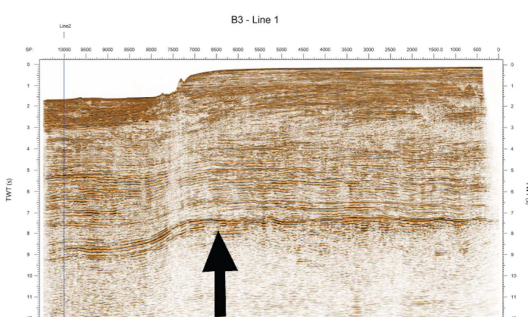

B3-01

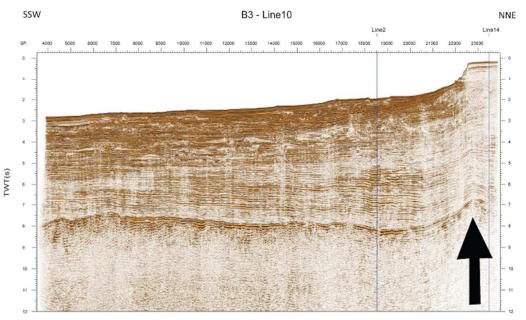

B3-10

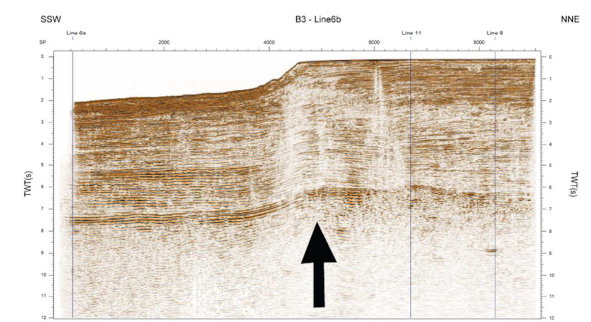

B3-06b

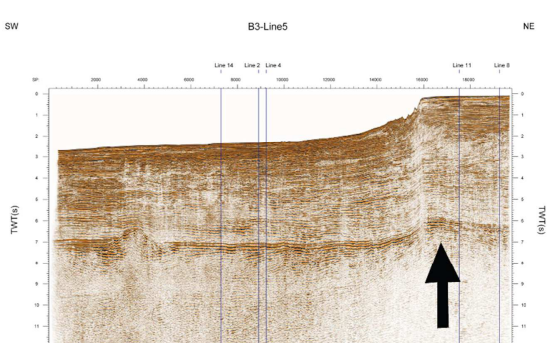

B3-05

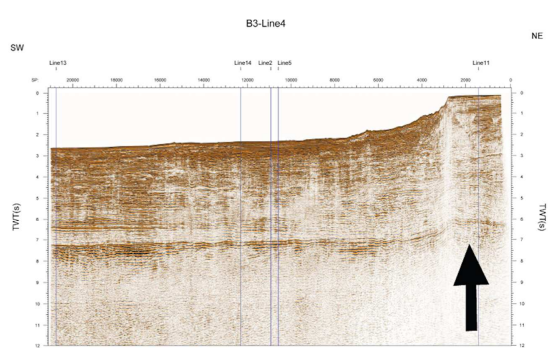

B3-04

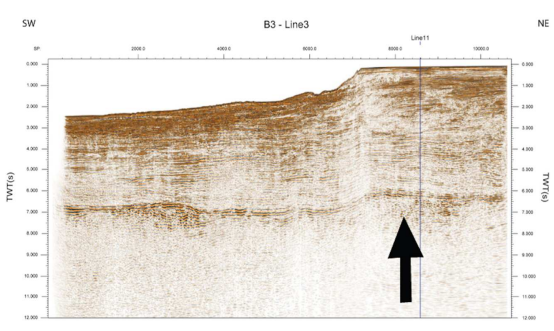

B3-03 


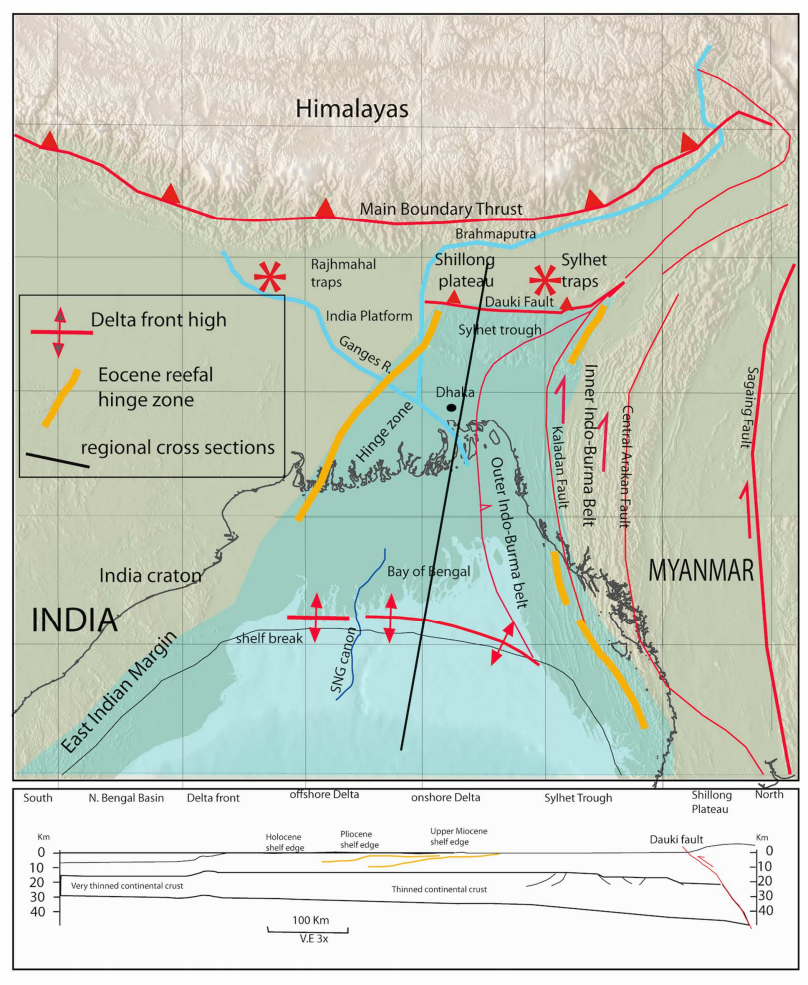




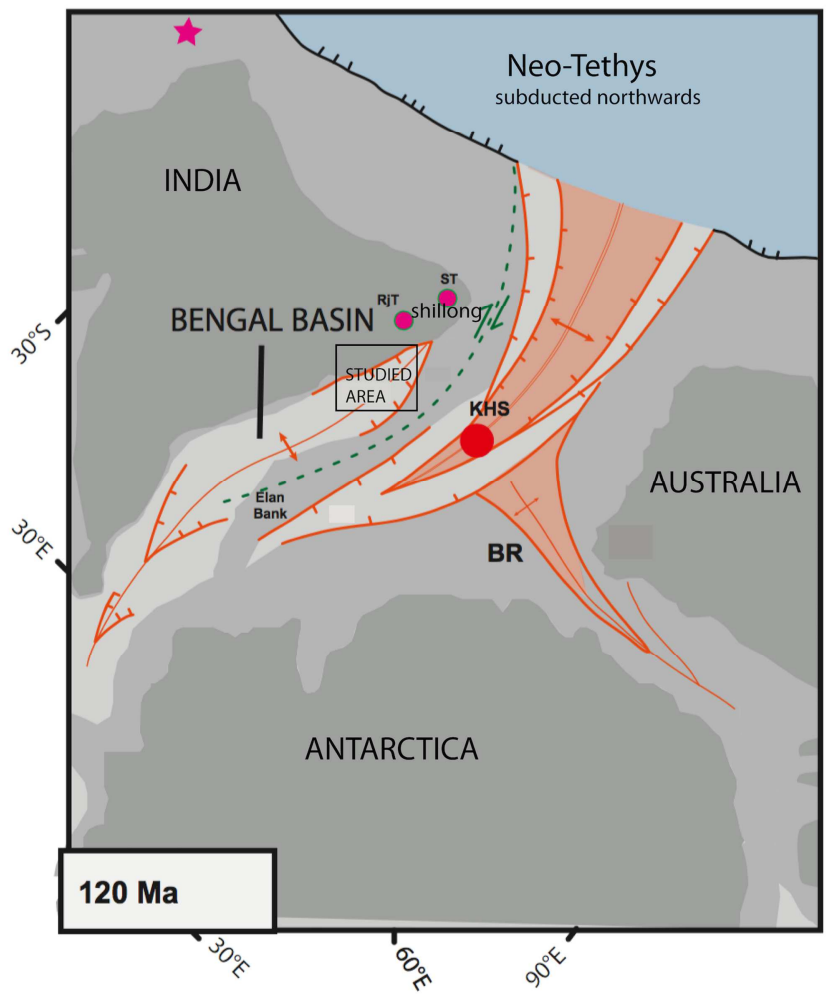

